\title{
A competency framework for the small business sector in Johannesburg South Africa
}

\author{
Adéle Bezuidenhout and Avhatakali Lazarus Nenungwi \\ Department of Human Resource Management, Preller Street, Muckleneuk Ridge, City of Tshwane, \\ P. O. Box 392, 0003, University of South Africa (UNISA), Republic of South Africa.
}

Accepted 27 August, 2012

\begin{abstract}
One of the most serious challenges that South Africa faces is the high unemployment level. The small business sector is globally recognised as a driver for job creation. However, low knowledge and skills levels in the South African population remain a serious problem and the lack of managerial knowledge and skills are often cited as the reason for the failure of small businesses. In addition, previous research confirmed that the education and skills level of an entrepreneur and the success of their business are related. One of the best ways to address unemployment is to leverage the employment creation potential of small businesses and to promote small business development through improving the competencies of the owners/managers of small businesses. The purpose of this study was to identify and prioritise the specific knowledge and skills that the owners'/managers' of small businesses need in order to succeed. A self-administered survey questionnaire was used to collect data from 88 small business owners/managers in Johannesburg. Descriptive, as well as inferential statistical analysis, were performed. Based on the results of the factor analysis, a conceptual competency framework for the owners/managers' of small businesses in South Africa was designed. The results of the study indicated that training needed in the areas of risk management, financial management, industry awareness and project management were significant. The four main competencies, as well as the ten underlying competencies are represented in the framework.
\end{abstract}

Key words: Small businesses, entrepreneurship, competencies, training needs, owners'/managers of small businesses.

\section{INTRODUCTION}

Unemployment has again been highlighted in South Africa with recent events such as the $62 \mathrm{~km}$ "Economic liberation" march by thousands of young people, between Johannesburg and Pretoria (Timeslive, 2011). South Africa is a developing country within the third world, with an estimated population of over 50.5 million people (SouthAfrica.info, 2011). One of the major stumbling blocks in the social and economic growth of South Africa is the high rate of unemployment that exists.

There is no consensus regarding the exact number of

*Corresponding author. E-mail: bezuia@unisa.ac.za. Tel: +27 12429 3141. Fax: +27 12429. the population that is unemployed. The official government estimations are approximately $25.7 \%$ for the second quarter of 2011 (Tradingeconomics, 2011). Different references however, provide different estimations, for example the CIA World Fact book (2011) estimates the unemployment rate of the South African youth, aged between 15 and 24 years, at a total of $48.15 \%$. According to Roos (2011) South Africa's latest unemployment figures make the country the one with the highest official unemployment statistics among 61 surveyed by Bloomberg. Another 100000 private-sector jobs were lost during the first few months of 2011.

For South Africa to prosper as a country and for its people to grow and develop, it is essential that unemployment be addressed. It is believed that 
entrepreneurship in the form of small businesses are central to job creation, economic growth, poverty alleviation and very important in the South African context, socioeconomic transformation (Neuland and Venter, 2004: 32). One of the best ways to address unemployment is to leverage the employment creation potential of small businesses and to promote small business development (FinMark Trust, 2006).

According to the National Small Business Act (DTI, 1996: 6) micro, very small, small and medium enterprises are collectively referred to as small businesses. Goldstuck (2004: 5) explains that there is a variety of characteristics that may be used to define small businesses, including number of employees, turnover, independent ownership, asset value, independent management, and the degree of formalisation. According to the National Small Business Act (DTI, 1996) the term small business means a separate and distinct business entity, including cooperative enterprises and nongovernmental organisations, managed by one owner or more. Small enterprises constitute the bulk of established businesses and may employ between five and approximately fifty employees. Small enterprises are usually owner-managed or controlled directly by the owner community. They are likely to operate from business or industrial premises, be tax registered and meet other formal registration requirements.

The South African government has high expectations from the small business sector to provide a steady stream of new jobs. As long ago as 1995, the South African government acknowledged that low skills and education levels are one of the most important reasons why South African small businesses fail (Peters and Brijal, 2011). Unfortunately, this is does not reflect in the current situation. Worldwide, up to $96 \%$ of small businesses fail within 10 years of inception. Longley (2006) reveals that over $50 \%$ of small businesses fail in the first year and $95 \%$ within the first five years. An alarmingly high failure rate of small businesses in South Africa of between 70 and $80 \%$ raises questions (Brink et al., 2003: 1). Globally, the Total Entrepreneurial Activity index is used to measures entrepreneurial activity on national level (Herrington et al., 2008). It is a reliable indicator of the success rate within the small business sector. South Africa has a Total Entrepreneurial Activity rate of $7.8 \%$, while it should be $13 \%$ to facilitate economic growth (Herrington et al., 2008: 4; World Bank, 2004: 32). The small business sector experience unacceptable failure rates in the first three years of existence. In South Africa, this failure rate is somewhere between 70 and $80 \%$, costing the South African economy millions (Barron 2000: 1; Streek, 2001: 41). Mbonyane and Ladzani (2011) studied small businesses in black South African townships and concluded that owners and managers should prioritise training. Supporting this idea, Olawale and Garwe (2010: 736) recommend that new small businesses should be assisted with training to improve their successfulness and to ultimately contribute to the alleviation of unemployment. Similarly, the Bank Seta in South Africa declared that small businesses in South Africa face a number of challenges, but a number of organisations (including Ntsika, the Dti, ABSA, SMBDCI) declared the lack of management skills to be the most important. An inability to manage effectively, decrease the potential success of the small business and that will have a negative effect on job creation and the alleviation of poverty.

\section{LITERATURE REVIEW}

The South African government declared its support for skills development in order to address the unemployment problem. The Skills Development Act (1998) and the Skills Development Levy Act (1999) together provide a framework for promoting skills development in the country. The purpose of this legislation is to improve the skills of the workforce, ensure an adequate supply of the right kind of skills needed, ensure that young people are adequately trained to an agreed standard, to facilitate the employment of people, develop entrepreneurs, who will in turn generate employment opportunities and develop a culture of lifelong learning in the country. This study specifically addresses the improvement of skills and competencies of entrepreneurs, in the hope that this will create jobs and have a positive effect on creating opportunities for employment in South Africa (BankSeta, 2012). In an effort to clarify the specific training needs of small businesses and to contextualise these, this article will elucidate the training needs of the small business sector in Johannesburg South Africa.

The seminal work of Rothwell and Kazanas (1994: 79) provided the core theoretical framework for this study. They defined a comprehensive organisational needs assessment as "a broad systematic examination of conditions conducted for the purpose of identifying general differences between what people should know or do and what they actually know or do" (Rothwell and Kazanas, 1994: 79). Knirk and Gustafson (1986: 31) referred to the process of determining the difference (gap) between what is and what is desired. A comprehensive need assessment will specify the gaps between what people should know, pertaining to this study, what the owner/mangers of small businesses should know and what they actually know (Erasmus and Van Dyk, 2003).

The owners/managers of small businesses experience a real need for effective training interventions. Current consensus is that the available training interventions do not equip small business owners/managers with the skills that they need in order to run their businesses successfully. Very little is known about the training experiences that are most useful for the small business owner/manager or the best way to prepare young 
entrepreneurs for success. Goldstein and Ford (2002) view workplace training as a systematic approach to learning and development to encourage individual learning and organisational effectiveness. The 2008 GEM survey (Herrington et al., 2008) confirmed that while the need for entrepreneurial training is high, the availability of such training is low. The quality of small business training interventions in South Africa was rated as very poor in the GEM report (Herrington et al., 2008). These findings confirm that a lack of human capacity is one of the key obstacles to small business growth and employment growth within South Africa. Driver et al. (2001: 38) agrees that the lack of "needed" training is one of the main obstacles to success within the South African small businesses sector.

The phenomenon of resource-driven training in South Africa may be attributed to the small business support structures (for example the Ntsika Enterprise Agency) established by the National Small Business Act (DTI, 1996: 8), with the purpose of expanding, coordinating and monitoring the provision of training. In reality, many of these structures offer generic, non-customised training. Sparhawk (1994) strongly believes that identifying training needs is the first step in a larger training process, leading the way to delivery and evaluation of the final training package.

Herrington et al. (2008: 31) determined that key constraints facing small businesses are a lack of financial support, a lack of effective training interventions and ineffective government policies on small businesses. He highlighted that of all 30 GEM countries who conducted the national experts' survey in 2008 , South Africa had the highest percentage of experts identifying successful training as a major limiting factor. According to Burke and Collins (2001), managerial problems are among the primary reasons for the failure of small businesses in developing economies. In the case of South Africa, these managerial problems arise from a lack of appropriate training.

According to the Services Seta (2001) small business enterprises lack the resources, time and insight to engage in constructive training interventions. Chaykowski and Slotsve (2003: 3) maintain that human resource development through training and skills development, is a primary determinant of productivity and broader economic growth of any country. The $80 \%$ failure rate of small businesses in South Africa is far too high.

The small business sector requires training that is needs driven. Needs driven training is training that is designed and developed to meet the specific needs of trainees. However, the reality in South Africa is that small business owners/managers are provided with resourcedriven training. Resource-driven training is training that is offered because it is the only training available as well as the most convenient, but this type of training does not address the specific needs of the trainees.

Training and education are generally considered to be one of the key ways in which to reduce the failure rate of small businesses throughout the world. A thorough analysis of the training needs of the owners/managers of small businesses may serve as a viable foundation for the development and implementation of effective training in the small business sector in South Africa.

A study conducted by the Bureau of Market Research (BMR) (Ligthelm, 2002: 102) revealed that the efforts on the part of government to stimulate small business development are not achieving the desired results. The BMR reports that the lack of growth in the small business sector may to a large extent be attributed to a lack of proper training. Training is a critical part of business. Training in business should directly support the business goals and objectives of the enterprise. If training is to be successful, it is essential that trainers tie the training solutions to the needs of the trainees (Biech, 2009: 52).

De Kock and Uhlaner (2001: 273) allege that there is a general misconception that a training needs analysis is an expensive and time-consuming exercise, exacerbated by the lack of formal human resources management structures and systems in small businesses and a general failure among training providers to understand the training needs of the small business sector (McGrath, 2005: 6). Competence is a prerequisite for success in any organisation or sector and, without the required competencies; small business owners/managers are not able to run their enterprises in a sustainable and profitable manner.

According to Analoui and Hosseini (2001: 785-94) it is essential that the managers of small businesses be equipped with adequate managerial knowledge and skills. Burke and Collins (2001: 244-56) maintain that a shortage of managerial skills is a primary reason behind the failure of small businesses in so many of the developing economies.

An Irish study revealed that small business managers need to be competent in financial management, business planning, cash flow control and marketing (Ryan, 2002: 420). Perks and Struwig (2005: 172) identified four categories of competencies required by small business managers, namely personal competencies, technical competencies, business competencies and management/ leadership competencies.

This study built on these internationally identified competencies and investigated the applicability of these competency shortages to the South African situation. According to Haasbroek et al. (2008: 446), training refers to the planned or systematic efforts on the part of an employer to facilitate the employees' learning of the knowledge, skills and behaviour required to perform their jobs. De Cieri and Holland (2006: 5) maintain that "development" differs slightly from education and training in the sense that it is not aimed at imparting a particular skill or knowledge but rather at preparing the individual to excel to higher levels of functioning and reasoning". It is necessary that both training and development needs be 
identified in the small business sector.

Meyer (2007: 114) elaborates by explaining that needs assessment seeks to answer the question of whether the organization's needs, objectives, and problems can be met or addressed by training. According to Brown (2002: 569), a training needs assessment is an ongoing process of gathering data to determine the training needs, so that training may be developed to help the organisation accomplish its objectives. This information is then used to select or design an appropriate Human Resources Development (HRD) intervention, ensuring a high probability of improving competency levels in the small business sector (Meyer and Opperman, 2008: 36). McClelland (2001: 12) adds to this by explaining that the primary goal of conducting a training needs analysis is to identify training needs as they currently exist or have the potential to exist in the future, and to design and develop ways and means both to address and to satisfy these needs in the most effective and efficient manner possible. Brown (2002: 570) rightly argues that conducting a training needs assessment is vital because it increases the chances of success of a training programme and ensures that the training solutions offered are relevant, timely and effective (Cook, 2005: 32). Commonly used methods include survey questionnaires, performance observations, performance tests, interviews and criticalincident analyses (Stanley, 2002: 8).

\section{Problem investigated}

The efforts on the part of the South African government to stimulate small business development and hence job creation are not achieving the desired results. This may be attributed to a large extent to a lack of proper training and management competencies (Lighthelm, 2002: 02). In an effort to investigate the specific training needs of small businesses this article will elucidate the training needs in terms of management competencies of the small business sector in Johannesburg South Africa. Against this background, the following hypotheses were formulated:

$\mathbf{H}_{1}$ : A list of the priority training needs in terms of management competencies of the owners/managers of small businesses can be compiled.

\section{Purpose}

The main objective of the study on which this article is based, was to compile a list of the management competencies needed by small business owners/ mangers in Johannesburg South Africa. To achieve the primary objective, the study addressed the following research question:

Can a list of the priority training needs in terms of management competencies of the owners/managers of small businesses in Johannesburg South Africa be compiled?

\section{RESEARCH DESIGN}

The study was exploratory in nature because the competencies required by small business managers have received very little research attention in South Africa.

\section{Situational context}

The main objectives of the study reported here were to determine and prioritise the training needs of small business owners/managers in Johannesburg, South Africa; and develop a conceptual small businesses management competency framework that may be used as a basis for small business management training interventions.

\section{Research population}

The research population for this study comprised $400(\mathrm{~N}=400)$ small businesses operating in Johannesburg. Three hundred and fifty of these small businesses were registered with the Roodepoort Chamber of Commerce and Industry and. 50 of the small businesses in the research population were not registered. The population for this study was made up of either small business owners or managers. Although most often enterprises are managed by the original owner, there are instances in which the owner, who is generally an entrepreneur, hires someone to manage the enterprise on their behalf. In instances where both owner and manager were actively involved in the day-to-day running of the enterprise, the person who was in charge of the overall management of the enterprise was asked to complete the questionnaire.

\section{Research sample}

A probability sampling method, namely, systematic random sampling, was used to select the units of analysis to be included in the study sample. A number from 1 to 400 was allocated to each small business in the research population. All the small businesses that were allocated an even number were selected to be included in the sample. A sample of 200 small business owners/managers $(n=200)$ were randomly selected from a population of four hundred small businesses $(N=400)$. A total of 200 questionnaires were hand delivered to the respondents who were owners or managers of small businesses in Johannesburg. Of these, 88 were completed correctly and returned to the researcher, resulting in a response rate of $44 \%$. A representative sample can be confirmed on account of the diverse nature of the respondents in terms of their age, gender, home language and level of education.

\section{Ethical approval}

All the respondents were required to complete an informed consent form. Participation was voluntary and participants could withdraw their participation at any stage. The anonymity of all the respondents was protected.

\section{Measuring instrument}

A quantitative research design, using a self-report questionnaire 
was used. The items were based on a four-point Likert scale. According to Cooper and Schindler (2001), a four-point scale may help to eliminate respondent errors such as leniency, central tendency and the halo effect. The items were based on the literature review and specifically the Canadian small business management competency framework (Alliance Sector Councils in Canada, 2007) and for a South African perspective, Kroon and Nieuwenhuizen's (2002: 159) small business management competencies were integrated.

\section{Validity and reliability}

In this study, there were several steps taken to ensure the validity and reliability of the data collection instrument. Validity encompasses both the accurate interpretability of the results (internal validity) and the generalisability of the results (external validity) (Grimm and Yarnold, 2002: 104). The questionnaire was circulated among a group of experts in the fields of training and development, small business management, entrepreneurship and research. The experts analysed, evaluated and moderated the questionnaire in order to ensure face validity of the questionnaire. The Cronbach's alpha (Cronbach, 1951: 297) for this questionnaire was 0.97, proving a very high level of reliability. Cronbach (1951: 297) judged 0.7 to be acceptable; hence 0.97 indicated a very high level of reliability.

\section{Statistical analysis}

Data was analysed with the statistical package for social sciences (SPSS: 2007). Analyses included descriptive statistics, as well as a factor and component analysis.

\section{RESULTS}

\section{Biographical profile of the respondents}

The biographical profile of the respondents included 33\% females and $67 \%$ males; respondents were slightly older, as $83 \%$ were older than 35 years of age. Regarding their population group, $40.9 \%$ were black, $21.6 \%$ coloured, $21.6 \%$ white and $15.9 \%$ were Asian. The respondents' qualification levels were as follows: $10 \%$ had no qualification, $26 \%$ had Grade $12.33 \%$ had a diploma and $21 \%$ had a first degree. The respondents' involvement in the small business represented: $56 \%$ were the owner of the business, $29 \%$ the co-owner and $15 \%$ the manager of the small business.

\section{Association between biographical variables and perception of competency}

Regarding the biographical variables, the current study revealed that there is little difference between the different groups and the perception of their training needs. This was true for all the different biographical pairing, except for age. As there was a significant correlation at the $5 \%$ level of significance, it implied a strong correlation. This was an indication that older owners/managers perceived themselves as less competent than their younger counterparts. As age was the only variable that was presented with a significant correlation, it is accepted that the other biographical variables are not associated with the respondents' perception of their competence.

\section{Respondents' perceived level of competence}

Table 1 provides an overview of the respondents' perceived level of competence in respect of each of the 14 small business management competencies.

As illustrated in Figure 1, a significant number of respondents rated themselves as not competent and very incompetent in risk management, financial management, industry awareness, project management and information technology. This finding indicates that respondents have significant training needs in these five competencies.

\section{Respondents' perceived level of importance of the competencies}

An overwhelming response, in favour of the importance of these 14 competencies, was recorded. $20 \%$ of the small business owners/managers indicated that the 14 competencies are all important to ensure success of the small business and $78 \%$ indicated that the 14 competencies are all very important.

\section{Analysis of the four priority competencies}

The article focuses on the four competencies identified as the most significant in the previous area. The results will be presented in order of priority, namely risk management, followed by financial management, industry awareness and project management. When the actual numbers are presented as percentages, $52 \%$ of the respondents indicated that they were not competent in respect of risk management, $51 \%$ indicated that they were not competent in financial management, while $46 \%$ indicated that they were not competent in respect of both industry awareness and project management respectively.

\section{Competency 1: Risk management}

The results indicated that $52 \%$ of the respondents perceived that they were incompetent and very incompetent in risk management. This competency refers to the ability of the small business owner/manager to manage all business risks ranging from financial risks, business risks, physical risks such as robberies, and natural risks such as storms and floods. In terms of 
Table 1. Respondents' perceived level of competence $(\mathrm{N}=88)$.

\begin{tabular}{lcccc}
\hline Competencies & Very incompetent & Not competent & Competent & Very competent \\
\hline Risks management & 8 & 38 & 18 & 24 \\
Entrepreneurship & 11 & 29 & 15 & 33 \\
Business planning & 6 & 22 & 40 & 20 \\
Marketing, sales and advertising & 3 & 29 & 35 & 21 \\
Financial management & 6 & 39 & 12 & 31 \\
Customer relations & 12 & 12 & 22 & 42 \\
Human resource management & 3 & 34 & 38 & 13 \\
Business operations & 8 & 29 & 17 & 34 \\
Industry awareness & 5 & 36 & 28 & 19 \\
Professionalism & 2 & 32 & 36 & 18 \\
Communication & 4 & 24 & 25 & 35 \\
Information technology & 20 & 29 & 9 & 30 \\
Inventory management & 12 & 25 & 28 & 23 \\
Project management & 6 & 35 & 33 & 14 \\
\hline
\end{tabular}

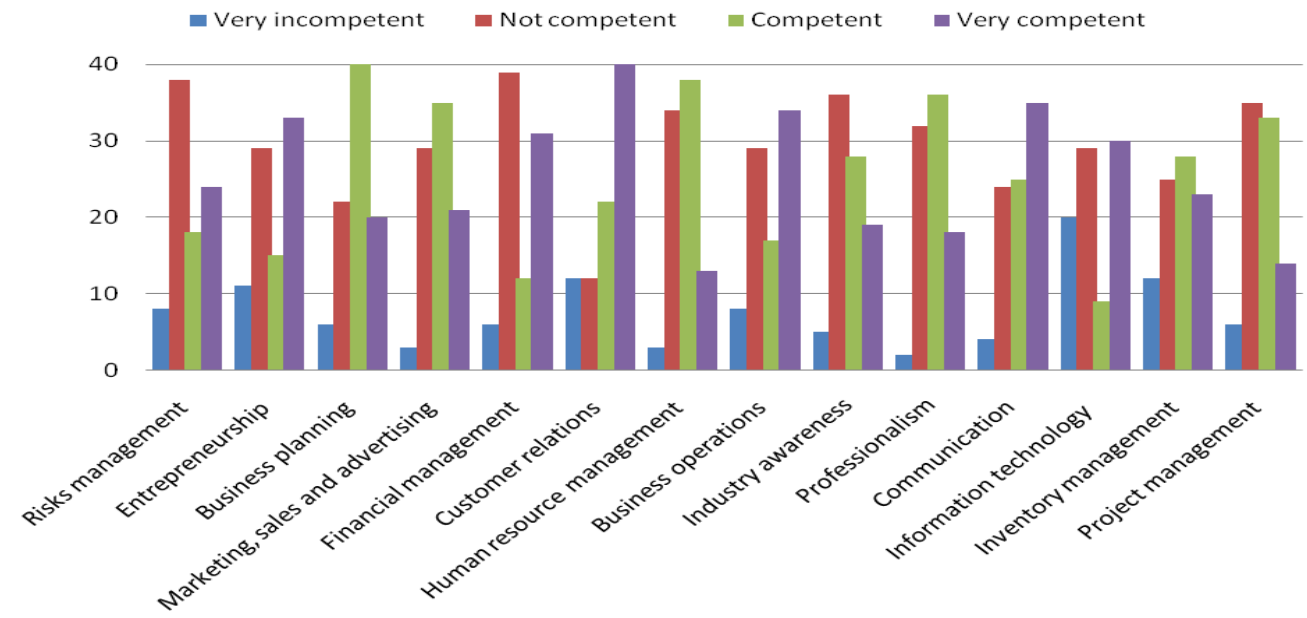

Figure 1. Respondents' perceived level of competence.

demographic variables, the results indicate that the majority of people without risk management competence are those respondents with a matriculation only (37\%). Those respondents with a postgraduate qualification comprised $1 \%$ only of this group. The $59 \%$ of respondents lacking risk management competence are owners of enterprises followed by co-owners at $26 \%$ and managers at $15 \%$. Respondents from medium enterprises constitute the highest percentage of people lacking risk management competence at $33 \%$. $50 \%$ of the respondents who lack risk management competence are from the tertiary economic sector with the other three sectors sharing $50 \%$.

\section{Competency 2: Financial management}

45 of the respondents indicated that they are either incompetent or very incompetent in financial management while 43 respondents indicated that they are either competent or very competent. Of the group that did not possess financial management competence $73 \%$ were male while $27 \%$ were female. $36 \%$ of the respondents who did not possess financial management competence were older than 46 years of age, followed by $27 \%$ in the age group between 41 to 45 years with $22 \%$ being less than 35 years of age. A significant $15 \%$ of the respondents who lacked financial management competence were between the ages of 36 and 40 . The majority of black respondents lacked financial management competence followed by whites and coloureds respectively. Regarding qualifications, 40\% had Grade 12 as their highest qualification; $17 \%$ had a post-school diploma; $16 \%$ had an undergraduate degree, $11 \%$ had no qualifications, $9 \%$ had a national diploma; $4 \%$ had a postgraduate degree while $2 \%$ had other unnamed 
qualifications. Hence, a clear trend emerged regarding the link between financial competence and level of education, namely that the lower the respondents' level of education, the higher their need for financial competence will be.

\section{Competency 3: Industry awareness}

Industry awareness refers to the ability of the owners/ managers to conduct industry research, to gather knowledge about the industry and to apply this knowledge in the running of their enterprises. This includes knowledge of industry best practices, competitors, market trends, products and service process, manufacturing and delivery standards, and legislation regulating the industry.

The majority of the respondents who lacked this competence were males (73\%), with $27 \%$ of the respondents lacking this competence being females. 32\% of respondents who lack industry awareness competency were over the age of $46,29 \%$ were in the age group of between 41 and $45,10 \%$ were in the age group of between 36 and 40 , while $29 \%$ were below the age of 35 . Of the respondents who lacked industry awareness competence, $39 \%$ were black, $21 \%$ were white, and $20 \%$ were coloured and $20 \%$ were Asian. $34 \%$ of respondents lacking industry awareness competence had Grade 12 as their highest qualification, followed by those with a degree at $17 \%$, those with a post-school diploma at $17 \%$, those with no qualification at $15 \%$, those with a national diploma at $12 \%$. This group were represented by $59 \%$ owners, $24 \%$ co-owners and $17 \%$ were paid managers.

\section{Competency 4: Project management}

Project management competence includes the ability of the owner/manager to design project plans and contracts, implement project plans, monitor project progress, manage the resources in a project, manage stakeholder relations and utilise project management tools. This group included $76 \%$ were males and $24 \%$ females; $34 \%$ were older than 46 years, $27 \%$ were younger than 35 years, $22 \%$ were between 41 and 45 years, and 17\% were between 36 and 40 years of age. Black respondents were in the majority (34\%), followed by coloured and white respondents at $24 \%$ each, and Asians at $17 \%$. Respondents without any qualification made up $14 \%$, those with Grade $1232 \%$, those with post school diplomas $20 \%$ and those with a national diploma at $7 \%$, those with a first degree at $20 \%$, those with a post graduate degree at $2 \%$ and those with unnamed qualifications $5 \%$. Owners were in the majority of those respondents who lacked project management skills (63\%) followed by co-owners at $2 \%$ and hired managers at $17 \%$.

\section{Factor analysis}

Factor analysis was used to reduce the data set, based on the assumption that the underlying dimensions or factors may be used to explain complex phenomena (Field, 2005: 619). A principal factor analysis was performed in this study (Morrison, 2000: 98). According to Garson (2008), principal factor analysis (PFA) is a form of factor analysis which seeks the least number of factors that can account for the common variance (correlation) of a set of variables, whereas the more common principal components analysis (PCA) in its full form seeks the set of factors that can account for all the common and unique (specific plus error) variance in a set of variables. Factor analysis is one of the most commonly used methods for data reduction in social science research. Factor analysis assumes that underlying dimensions or factors can be used to explain complex phenomena. A single factor can then consist of a number of items with the same underlying characteristics.

Sample size, however, plays an important role and some of the problems associated with using factor analysis can be directly ascribed to a small sample size. Small samples present problems due to various forms of sampling error, which can manifest itself in factors that are specific to one data set. The following two measures were used as further proof that factor analysis is justified.

The Kaiser-Meyer-Olkin (KMO) measure of sampling adequacy is an index for comparing the magnitudes of the observed correlation coefficients to the magnitudes of the partial correlation coefficients (refer to SPSS User's Guide). Large values for the KMO measure indicate that a factor analysis of the variables is a good idea.

Another indicator of the strength of the relationship among variables is Bartlett's test of sphericity. Bartlett's test of sphericity is used to test the null hypothesis that the variables in the population correlation matrix are uncorrelated.

Because of the relatively small sample size, caution should be exercised when these results are interpreted, though the investigation indicated the presences of two components, as illustrated in Table 2.

In view of the fact that a maximum of $63.114 \%$ of the total variance is explained by the two components, further data reduction was not possible. As a consequence, $36.886 \%$ of the variance remains unexplained. Nevertheless, it is interesting to note that the two components naturally split into an "interpersonal" and a "business intelligence" factor. Customer relation skills, human resource management skills, professionalism, communication skills and inventory management skills were grouped together, representing the "interpersonal" category. A skill in risk management, business planning, marketing, sales and advertising skills and financial management skills belong together and represent the "business intelligence" category. To summarise, the respondents manifested with an overarching need for 
Table 2. Factor analysis.

\begin{tabular}{ll}
\hline Factor 1: Interpersonal factor & Factor 2: Business Intelligence \\
\hline Customer relation skills & Business risk management skills \\
Human resource management skills & Business planning skills \\
Professionalism & Marketing skills \\
Communication skills & Sales skills \\
Inventory management skills & Advertising skills \\
& Financial management skills \\
\hline
\end{tabular}

training to become competent in both interpersonal aspects, as well as in business intelligence. Based on the empirical evidence, as discussed, the hypothesis was therefore accepted:

$\mathrm{H}_{1}$ : A list of the priority training needs in terms of management competencies of the owners/managers of small businesses can be compiled.

To answer the research question, the results can be summarised as follows:

A list of the priority training needs in terms of management competencies of the owners/managers of small businesses in Johannesburg South Africa was compiled. A significant number of respondents rated themselves as not competent and very incompetent in risk management, financial management, industry awareness, project management and information technology. This finding indicates that respondents have significant training needs in these management competencies. Furthermore the factor analysis revealed that two overriding factors emerged from the empirical evidence, namely an interpersonal factor and a business intelligence factor.

Hence, the main objective of the study was achieved, as illustrated in Figure 3. These findings will now be discussed in more detail.

\section{DISCUSSION}

From the literature review the dire need for diagnosing and addressing the skills deficiencies of small business owners and managers in South Africa, to ensure success and consequently, job creation was clear. Numerous Global Entrepreneurship Monitor reports (Driver et al., 2001; Herrington and Maas, 2007; Herrington et al., 2008 ; 2004) noted that the lack of education and training is the major inhibitor of entrepreneurial growth in South Africa. From these reports, it is particularly noteworthy that the lack of appropriate education and training is problematic nationwide in the age group 18 to 34 years in South Africa. Moreover, the South African school system does not encourage critical thinking, nor entrepreneurial skills (Nicolaides, 2011). The small business sector experience unacceptable failure rates in the first three years of existence. As mentioned in the literature review, the failure rate is approaching $80 \%$, costing the South African economy millions (Barron, 2000: 1; Streek, 2001: 41). Mbonyane and Ladzani (2011) emphasized the importance of prioritise training for small business owners in black townships. Supporting this idea, Olawale and Garwe (2010: 736) recommend that new small businesses should be assisted with training to improve their successfulness and to ultimately contribute to the alleviation of unemployment. Similarly, the BankSeta (2012) emphasised the lack of management skills for entrepreneurs. An inability to manage effectively decreases the potential success of the small business and that will have a negative effect on job creation and the alleviation of poverty.

The South African government declared its support for skills development in order to address the unemployment problem. The Skills Development Act (1998) and the Skills Development Levy Act (1999) together provide a framework for promoting skills development in the country. The purpose of this legislation is to improve the skills of the workforce, ensure an adequate supply of the right kind of skills needed, ensure that young people are adequately trained to an agreed standard, to facilitate the employment of people, develop entrepreneurs, who will in turn generate employment opportunities and develop a culture of lifelong learning in the country. This study specifically addresses the improvement of skills and competencies of entrepreneurs, in the hope that this will create jobs and have a positive effect on creating opportunities for employment in South Africa (BankSeta, 2012).

As a result of the factor analysis, a conceptual framework of the competencies necessary to ensure success is offered in Figure 2. This conceptual competency framework supports the viewpoint of Woldesenbet et al. (2011) that the different small business competencies together creates synergy and underpins a higher-order dynamic capability, imperative to small business success and sustainability in South Africa. International research indicates that entrepreneurial capabilities are intertwined in subtle and complex ways in many of the other small business competencies. Hence, a holistic approach where all the competencies will be addressed systematically is crucial. 


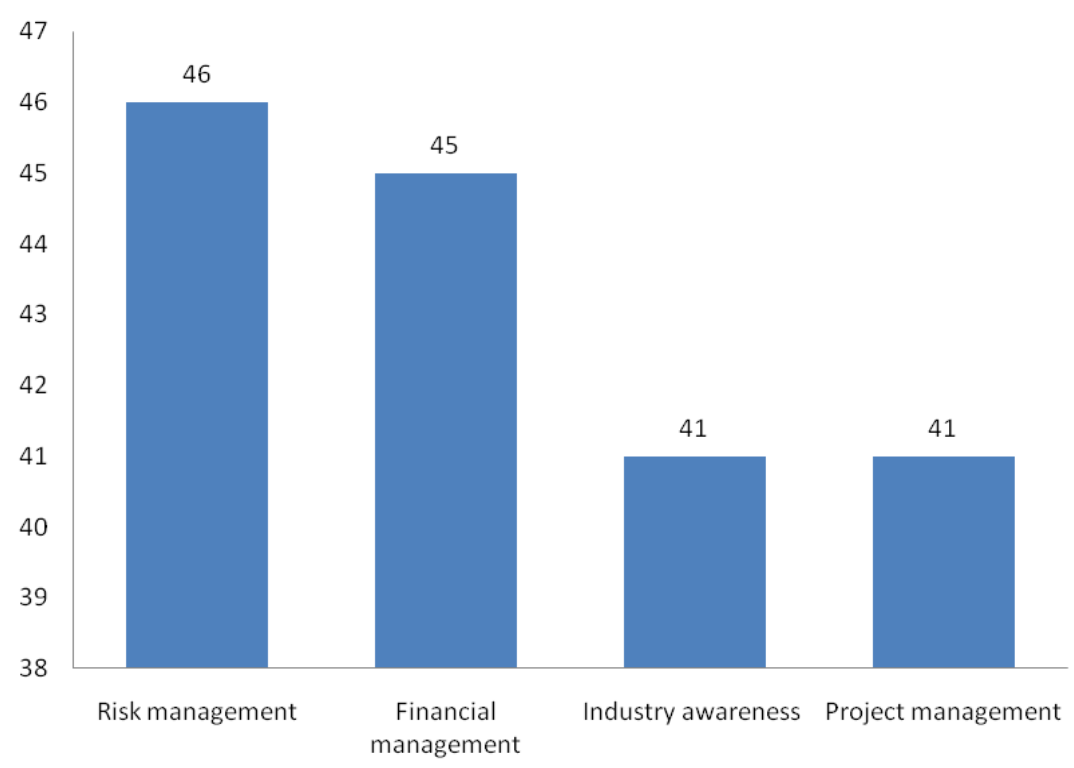

Figure 2. The priority small business management competencies.

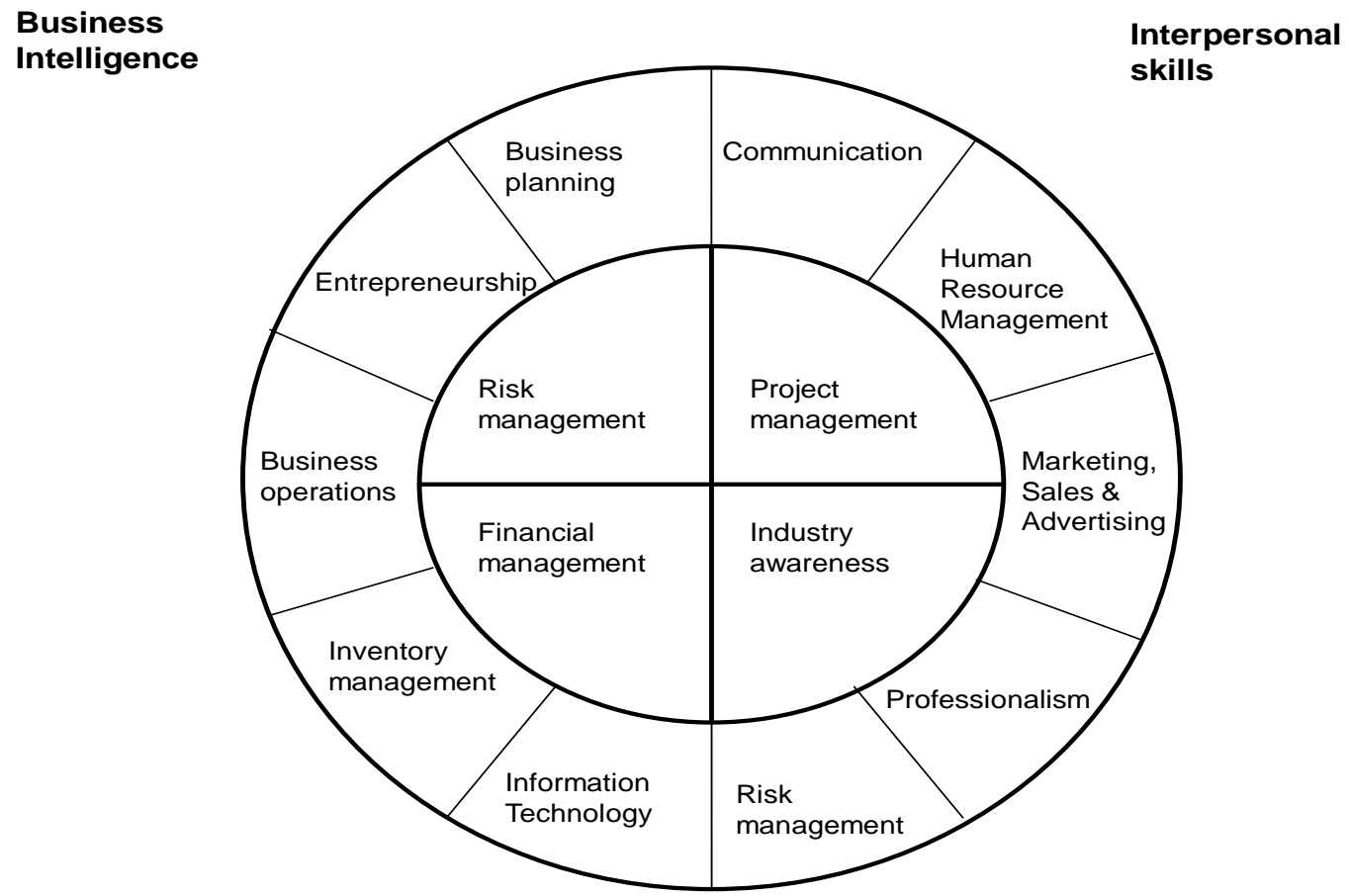

Figure 3. Conceptual model of a competency framework for small business owners/managers. ()

The framework was compiled systematically from the empirical findings. Firstly, the 14 core competencies identified from the international literature review served as the foundation. The statistical analysis revealed the four most important competencies, as manifested in this study. These four competencies are indicated in the centre, to symbolise their importance to the success of the small business. Secondly, the results of the factor analysis revealed that the identified training needs can be grouped together into two overarching needs, namely business intelligence and interpersonal skills. The competencies that represent business intelligence are grouped together on the left hand side and the interpersonal skill competencies on the left hand side. 
Regarding business intelligence, Mbonyana and Ladzani (2011) likewise concluded from their research that a general lack of business knowledge is a major cause of failure of small businesses in black townships in South Africa.

It is noteworthy that the four identified core training needs are also reflected in comparative research findings in South Africa and globally. Small businesses operate in a hostile external environment containing many legal constraints, limited access to financial support and ever increasing national and international competition. Moreover, natural disasters such as floods, global recessions, international political upheaval such as the Arab Spring of 2011 and political instability of neighboring countries can all have dire consequences for the small business sector. Naturally, it is essential for entrepreneurs to proactively identify and respond to potential risks to survive.

Regarding business operations skills, Urban and Naidoo (2012) explored the relationship between operations skills and small business sustainability in South Africa. They found significant correlations between operations skills and sustainability. To complicate the matter, they argue that entrepreneurs are normally generalists (Hodgetts and Kuratko, 1989) and therefore do not have the specialized skills required in business operations. Hence, the findings of Urban and Naidoo (2012), supports the findings of this study. Therefore, the small business sector needs to master the technical skills involved in operations management, if they are to be successful and sustainable.

Effective financial management includes proper inventory management. Cost-effective inventory management includes balancing the cost of inventory with its profit. Many small business owners are oblivious to the monitory value of the cost of carrying inventory, which include the cost of storage, insurance and lack of liquidity because of the businesses' money being tied up in inventory. Running inventory using paper-based systems or even outdated excel spreadsheets is a costly and resource-intensive approach. It is crucial that small businesses managers acquire the knowledge and skills needed to manage inventory effectively and efficiently (Mathaba et al., 2011).

Closely related to inventory management is information technology. Mathaba et al. (2011) believes that small business owners and managers need to be trained in information technology, as it will improve business performance, managerial competence and increase flexibility and responsiveness to the external environment (which in turn is related to risk management). Information technology competence can transform the small business past mere survival into becoming a vibrant, growing entity.

The results of this study have implications for small business owners and managers, the public and private institutions that provide education, training and development services to small business owners/ managers, as well as other service providers by the increased awareness on the nature and associations that operational skills have on developing sustainable businesses.

This includes the sector education and training authorities, which are mandated to provide education, training and development activities within different sectors. It is recommended that the small business management competency framework developed in this study be used to design applicable curricula for entrepreneurial courses. The primary contribution of this study is the list of priority training needs for the owners/ managers within the small business sector (Figure 2) that the study produced. Supporting recommendations include training for small business owners/managers should focus specifically on risk management, industry awareness, financial management, and project management, in order of priority. It is recommended that the new department of higher education and training would amend the Skills Development Act (RSA, 1998) in order that the Social Enterprise Training and Support (SETAS) may be aligned to this new department. This amendment should also encompass the establishment of a new Sector Education Training Authority dedicated to small businesses. It is recommended that it regulates the quality and relevance of the training provided to small businesses by private and public training service providers. It is recommended that in order to improve the success rate of small businesses is training service providers would align training interventions with the 14 competencies tested in this study. Greater emphasis should be placed on the four priority training needs area, which were identified and analysed in this study, namely, risk management, financial management, industry awareness and project management.

\section{Conclusions}

In attempting to identify priority training needs in the small business in Johannesburg, the empirical results revealed that financial management, risk management, industry awareness and project management are the priority training needs. This study has confirmed that, although small businesses offer hope for economic growth in South Africa, the small business sector is not immune to the problem of skills shortage. The skills shortage is a major dilemma facing the government of South Africa. The results of this study may be used as a foundation in the post economic recession efforts to revive the small business sector. There is evidence that a lack of management capacity and skills among small business owners/managers is one of the major reasons for the high failure rate of businesses in the small business sector. Training in small business management skills with special emphasis on the four priority areas identified in 
this study may, potentially, be a solution to the many problems facing small businesses in South Africa. Effective training in the small business sector is likely to result into a higher success rate of businesses in the sector. This would, in turn, increase employment opportunities. The results of this study provide a basis for the prospect of a better life for all in South Africa.

\section{REFERENCES}

Alliance of Sector Councils (2007). A framework: Management of competencies, skills, and standards for small business owner/operator/entrepreneur for the Sector Councils Steering Committee. Available from http://www.councils.org/1small_business/guideline/index_e.cfm.

Analoui F, Hosseini M (2001). Management education and increased managerial effectiveness: the case of business managers in Iran. J. Manag. Dev. 20(9):785-794.

BankSeta (2012). Small and Micro Enterprises. Enabling skills development in the banking and micro finance sectors. Available from http://www.bankseta.org.za.

Biech E (2009). Learning eye to eye: aligning training to business objectives. J. Train. Dev. 8(4):50-53.

Brink A, Cant M, Lighthelm A (2003). Problems experienced by small business in South Africa. (Paper read at the Annual Conference on Small Enterprise Association of Australia and New Zealand, June 10, University of Ballarat, Australia). Unpublished.

Brown J (2002). Training needs assessment: A must for developing an effective training program. Public Person. Manage. 31(4):569-578.

Burke S, Collins K (2001). Gender differences in leadership styles and management skills. J. Women Manag. Rev. 16(5):244-56.

Chaykowski R, Slotsve G (2003). Employer sponsored training by firm size, Skills Research Initiative, Working Paper 2003 B-02, Human Resources Development. Canadian Soc. Sciences and Humanities Research Council, Ottawa.

CIA World Factbook (2011). Available from http://www.indexmundi.com/south_africa/youth_ages_15-

24_unemployment.html.

Cook S (2005). Learning needs analysis: Using technical tests and one-one-one interviews to analyse performance gaps. Train. J. 16(9):32-35

Cooper DR, Schindler PS (2001). Business research methods, $7^{\text {th }}$ ed. Boston: McGraw-Hill Irwin. MA.

Cronbach LJ (1951). Coefficient alpha and the internal structure of tests. Psychometrika 16(3):297-334.

De Cieri H, Holland $P(2006)$. The strategic role of human resource development. Australia: Pearson Prentice Hall.

De Kock JMP, Uhlaner LM (2001). Organization context and human resource management in the small firm. Small Bus. Econ. 17(10): 273-291.

Driver A, Herrington M, Segal N, Wood E (2001). Global entrepreneurship monitor: South African executive report. University of Cape Town Centre for Innovation and Entrepreneurship.

Erasmus BJ, Van Dyk PS (2003). Training Management in South Africa. Cape Town: Oxford.

Field A (2005). Discovering Statistics using SPSS. $2^{\text {nd }}$ ed. London:Sage.

FinMark Trust (2006). FinScope Small Business Survey Report [online]. Available: http://www.finmarktrust.org.za Accessed: 15 November, 2009.

Garson GD (2008). Factor analysis: stat notes, from North Carolina State University, Public Administration Programme. Retrieved November 11, 2007, from North Carolina State University website: http://www2.chass.ncsu.edu/garson/pa765/factor.htm.

Goldstein IL, Ford KJ (2002). Training in Organisations: Needs assessment, development and evaluation. Belmont, CA: Wadsworth Thomson Learning.

Goldstuck (2004). SME Survey 2004. Johannesburg Worldwide Works. Government Gazette 26 November. South Africa. Department of Labour.
Grimm LG, Yarnold PR (2002). Reading and understanding more multivariate statistics. Washington DC: American Psychological Association.

Haasbroek GD, Nel PS, Poisat P, Schultz HB, Sono T, Werner A (2008). Human resources management. 7th ed. Cape Town. Oxford University Press.

Herrington M, Kew J, Kew P (2008). Global Entrepreneurship Monitor: South African Report. University of Cape Town Centre for Innovation and Entrepreneurship. UCT Graduate School of Business: Cape Town.

Herrington M, Maas G (2007). Global Entrepreneurship Monitor: South African Report. University of Cape Town Centre for Innovation and Entrepreneurship. UCT Graduate School of Business: Cape Town.

Herrington M, Orford J, Wood E (2004). Global Entrepreneurship Monitor: South African Report. University of Cape Town Centre for Innovation and Entrepreneurship. UCT Graduate School of Business: Cape Town.

Hodgetts KM, Kuratko DF (1989). Effective Small Business Management, Harcourt Brace Jovanovich Publishers: San Diego, CA.

Knirk FG, Gustafson KL (1986). Instructional technology: a systematic approach to education. New York:CBS. Knowledge resources: Randburg.

Kroon J, Nieuwenhuizen C (2002). Identification of entrepreneurial success factors to determine the content of entrepreneurial subjects. March. SA. J. Higher Educ. 16(3):157-166.

Ligthelm A (2002). Research report: Small-scale enterprise development in the Tshwane Metropolitan municipality: Problems and prospects. Pretoria: BMR, Unisa.

Longley $R$ (2006). SBA says $50 \%$ fail during first year. Why small businesses fail. SBA. Available from: http://usgovinfo.about.com/od/small/business/a/whybusfail.htm.

Mathaba S, Dlodlo N, Smith A, Adigun M (2011). Use of RFID and Web 2.0 technologies to improve inventory management in South African enterprises. Electronic J. Inform. Syst. Eval. 14(2):228-241.

Mbonyane B, Ladzani W (2011). Factors that hinder the growth of small businesses in South African townships. Eur. Bus. Rev. 23(6):550 560.

McClelland SB (2001). Training needs assessment: An open-systems approach. J. Eur. Ind. Train. 18(1):12-17.

McGrath S (2005). Skills development in very small and micro enterprises in South Africa: Research programme on human resources development. Cape Town: HSRC Press.

Meyer M (2007). Managing human resource development: An outcomes-based approach. Durban: Lexis Nexus.

Meyer M, Opperman C (2008). Integrating training needs analysis, assessment and evaluation: aligning learning with business results.

Morrison A (2000). International professional development program: Quality and impact assessment. Glasgow, Scotland: Scottish Tourism Research Unit, University of Strathclyde.

Neuland E, Venter D (2004). Globalisation: creating entrepreneurship within NEPAD. January. Manag. Today 20(1):29-33.

Nicolaides A (2011). Entrepreneurship- the role of Higher Education in South Africa. Educ. Res. 2(4):1043-1050.

Olawale F, Garwe D (2010). Obstacles to the growth of new SMEs in South Africa: A principal component analysis approach. Afr. J. Bus. Man. 4(5):1993-8233.

Perks S, Struwig M (2005). Skills necessary to grow micro entrepreneurs into small business entrepreneurs: Management. SA. J. Econ. Manag. Sci. (SAJEMS) 8(2):171-186.

Peters RM, Brijlal P (2011). The relationship between levels of education of entrepreneurs and their business success: a study of the province of KwaZulu-Natal, South Africa. Ind. Higher Educ. 25(4):265-275.

Roos P (2011). SA unemployment rate among highest. http://www.fin24.com/Economy/SA-unemployment-rate-amongworlds-highest-2011.

Rothwell WJ, Kazanas HC (1994). Human Resource Development: A strategic approach. Massachusetts: HRD.

Ryan E (2002). Management development-a model for retail business. J. Eur. Ind. Train. 26(9):420-429.

Services Seta (2001). Sector Skills Plan: executive summary 2001.

SouthAfrica.info (2011). South Africa's population. Available from 
http://www.southafrica.info/ about/people/population.htm.

Sparhawk S (1994). Identifying targeted training needs: A practical guide to beginning an effective training strategy. Irvine(CA): Richard Chang. pp.1-104.

Timeslive

(2011).

Avaiable

from http://www.timeslive.co.za/politics/2011/joburg-pretoria-brace-formalema-s-m.

Tradingeconomics (2011). South Africa Unemployment Rate. Available from http://www.tradingeconomics.com/south-africa/unemploymentrate.

Urban B, Naidoo R (2012). Business sustainability: empirical evidence on operational sustainability: empirical evidence on operational skills in SMEs in South Africa, J. Small Bus. Enterprise Dev. 19(1):146163.
Woldesenbet K, Ram M, Jones T (2011). Supplying large firms: The role of entrepreneurial and dynamic capabilities in small businesses. Int. Small Bus. J. 30:1.

World Bank (2004). Global Economic Prospects, e-version, World bank. Available from www.developmentgoals.org/ (Accessed 24 March 2008). 